\title{
RUSSIAN PERCEPTIONS OF U.S. LAWYERS AS A LINGUAL-CULTURAL TYPE
}

\author{
Evgenia Gulyaeva \\ Academy for Public Administration, Volgograd, Russia
}

\begin{abstract}
This article introduces the reader to the theory of a lingualcultural personality and lingual-cultural types in particular. A lingualcultural type is a generalized image of personalities whose behavior and values significantly influ-ence the culture in general and is a representative of ethnic and social variety of the society. The type of an American Lawyer is being analyzed, because in the United States of America, unlike any other country, the role of a lawyer has a pervasive shared understanding. The author examines how lawyers are repre-sented in US popular culture, specifically exploring presentations in legal and crime fiction. She also analyzes results from a survey of 100 Russian students, exploring their perceptions of the lingual-cultural type of US lawyers.
\end{abstract}

Keys words: sociolinguistics, lingual-cultural type, lawyers, Russia, USA

"Lawyers are... the High Priests of America. We alone know the words that made America. Out of this air. We alone know how to use The Words. The Law: the only club I ever wanted to belong to. And before they take that from me, I'm going to die" (Kushner 221). Roy Cohn's statement near the end of his life in Kushner's Perestroika sums up the public perception of the typical personality of the American attorney. This perception may or may not be accurate, but to a cer-tain extent reality does not always play much of a role in the establishment of per-vasive stereotypes surrounding a certain type of 
person or a certain profession. Ne-vertheless, these perceptions play a role in our linguistic and cultural realities.

Nowadays in the Russian linguistic school it is becoming more and more po-pular to study personality. Anthropocentric Linguistics focuses its attention on the problems of correlation of language and a person on the one hand and of language and culture on the other hand. Dealing with phenomenon of a person in language scientists realized the importance of investigations connected with a lingual perso-nality. The linguistic cultural description of lingual personalities presents them as a generalized cultural personality types recognized by all bearers of a certain culture (Dmitrieva "Communicative", Karasik "Communicative", Yarmakhova).

The studying of a personality in the lingua-cultural studies takes into account the achievements in the fields of psychology, sociology and linguistics. From the side of psychology the special attention is given to neurophysiological and deviant characteristics of the personality. From the sociological part the personality is de-termined as a member of some social group, therefore the attention is paid to fea-tures of a personality either from a micro or a macro group. From the linguistic side, a personality is defined as a bearer of some communicative norms and speech displays of the linguaculture. And finally from a position of lingua-cultural stu-dies, a personality represents a cultural personality type - a generalized image of personalities whose behavior and values significantly influence the culture in gene-ral and is a representative of ethnic and social variety of the society.

A lingual-cultural personality type is a kind of lingual-cultural concept because it represents the full spectrum of experienced knowledge about a typical re-presentative of a society. The notion "a lingual-cultural type" is closely connected with such notions as "model personality", "role", "image", "stereotype", "language portrait". A lingual personality studied from the positions of a typical lingual-cul-tural variety becomes a lingual-cultural type. In other words the notion of a lingual personality is broader and the study of a lingual-cultural type is one of the ap-proaches to study a linguistic personality. It is important to keep in mind that the distinction of types is made according to their influence on the culture. For exam-ple, we can single out model personalities, who are either imitated or countervailed by representatives of the same culture. The main characteristic of these persona-lities is the establishment of value behavior orientations. However, society does not consist of model personalities only. A lingual personality is a complex formation, 
consisting of socio-situational roles, behavioral modus, levels of communicative competence, and individual peculiarities. A lingual-cultural type represents a cer-tain model personality with a set of unique characteristics peculiar to this culture, so it is a symbol of a culture for a culture and may also be a symbol for represen-tatives of other nationalities. However, unlike model personalities whose behavior is standard and who represents a model to follow, a lingual-cultural type is not such an example.

In the communicative mass consciousness, a type may have both a positive and negative characteristic. With time changing and values changing in society, a model personality may turn into a lingual-cultural type. For instance, it may be connected with some ideological factors. For example, in the Soviet Union for more than 70 years the type "komsomol member" was a model personality. All children were expected to become such models, smart, socially active, ideo-logically oriented. The country and the society have changed and now "komsomol member" can be called a type with certain positive as well as negative charac-teristics (Dmitrieva "Lingual-cultural").

In analyzing the correlation between the notions "image" and "lingualcultural type" I would note that image is created with the aim of making the personality po-pular in the mass consciousness; it is formed deliberately, but a lingual-cultural type appears spontaneously as a result of a societal development.

The most important sense distinctions for the notion "lingual-cultural type" consist of a combination of factors how typical a certain lingual personality is, what significance this lingual personality has for the culture, whether or not there is a presence of values forming a concept, how it is concretized in a real individuality or in a novel character, and how the type is described with the help of special so-ciolinguistic and lingual-cultural methods.

A stereotype as a ready-made scheme of perception is a relatively stable and simple image of a social object or an event, or a group of people. Stereotypes ap-pear as a result of summarizing individuals' experiences and often biased ideas, ac-cepted in society (Karasik Language).

\section{METHOD}

In my work I am studying a type "an American lawyer" - a lingualcultural type which is not considered to be a model personality, so it is not 
imitated or followed; however, it forms a specificity of an American lingual culture. I have chosen the type of an American lawyer to study because in the United States of America, unlike any other country, the role of a lawyer is dominant. For this research, I examine how lawyers are represented in US popular culture, specifically exploring presentations in legal and crime fiction. I also analyze results from a survey of 100 Russian students, exploring their perceptions of the lingual-cultural type of US lawyers.

\section{FINDINGS}

In the Russian Federation, for instance, lots of cases are argued without attorneys. In the USA on the contrary, to come to court without a lawyer is nonsense! The right to have a lawyer's help in court is a significant social good, which is secured on the constitutional level. Defendants must have legal represen-tation and they are vigorously dissuaded from serving as their own legal repre-sentation. The $6^{\text {th }}$ amendment of the Constitution of the United States of America states,

"In all criminal prosecutions, the accused shall enjoy the right to a speedy and public trial, by an impartial jury of the state and district wherein the crime shall have been committed, which district shall have been previously ascertained by law, and to be informed of the nature and cause of the accusation; to be confronted with the witnesses against him; to have compulsory process for obtaining witnesses in his favor, and to have the assistance of counsel for his defense." (US Constitution)

I have analyzed a wide sample of documentation on the US legal process and the role of the attorney, including fiction, non-fiction, films, legal documents, and surveys. The breadth of this type of material allows us to access the lingual-cultural type of the attorney in the US society.

In fiction, I have examined a range of authors who write about legal and cri-minal issues. I pull examples primarily from the work of John Grisham who is one of the most widely recognized and respected authors of legal fiction. He is impor-tant not only because of his reputation as a writer of legal fiction, but because is an attorney himself and he had a reputable legal career before he began in popular cul-ture writing. I work from other crime and detective fiction writers, including Mary Higgins Clark, Sandra Brown, Danielle Steele, Harold Robbins, Dashiell Ham-mett, and S. Woods, because of the perspective they 
offer on the pervasive shared understanding of and perceptions of attorneys in society.

The following example from Brown offers insight into the assumption of le-gal representation by an attorney in the United States. In stark contrast to practices of legal representation in the Russian Federation, Brown's attorney character, Ken-dall, displays the widely held understanding of the constitutional right to legal re-presentation in the US, even as she subtly points out that this awareness is not just among the educated, but among average citizens and criminals. The point is made that in the US, as long as there are criminals, there will be lawyers.

"My job is to provide legal counsel for those who can't afford their own attorney. The Constitution grants every US citizen legal representation."

"I know what the Constitution grants," he said testily.

Kendall smiled to take the sting out of her mild insult.

"Sometimes I must remind myself. My work brings me in close contact with an element of society we all wish weren't there. But as long as there are criminals, they will need someone to plead their cases in court. No matter how unsavory my client, I try to plead every case to the best of my ability."

This scene also highlights the way in which attorneys see themselves. Ken-dall, the attorney, positions herself as a dedicated upholder of the constitution and as an ethical servant of the values of the US legal system.

But let's get back to the theory of the lingual-cultural type. Here, I provide a detailed description of the lingual-cultural type "American lawyer" based on the questionnaires answered by students in Russia. The surveys reveal that for the stu-dents, the following characteristics form the type of an American lawyer:

1. Appearance. Russian students, who were asked to describe the way a typical American lawyer looks like, usually said that lawyers are dressed profes-sionally; they are clean in their style of dress. Most of the time they wear a black suit, shiny black leather shoes and they carry a briefcase in one hand and a venti cup of coffee in the other. The last is an inevitable item of his war-drobe. The man would have a short hair cut and the woman would have her hair tightly pulled back into a bun or ponytail. Women usually wear skirts with blazers and don't dress sexually. It is 
interesting to note that students picture most lawyers being Caucasian or Jewish.

2. Age: in his/her thirties. The lawyer respondents depict is a young person.

3. Gender. Male. Very seldom female. Women-lawyers do come to mind, but it still feels that this field is male-dominated.

4. Background and education. Usually upper-middle class is mentioned. $100 \%$ of students have said lawyers go through a lot of schooling, they are very edu-cated and possess an extensive knowledge both in the field of law and its ap-plications and in general fields. Harvard, Stanford, or Yale Law schools have been mentioned. Lawyers have to start off small and work their way up the corporate career. In school they would have been at the top of their class. They are very intelligent, witty, and smart. Becoming a lawyer involves an extensive amount of time towards studying. They have to pass a Bar exam, which each of the respondents mentioned to be extremely hard. Sometimes the fact that a lawyer originally comes from not a very rich a family is men-tioned, but he is usually a self-made man. The students perceive that in an American culture it is typical to go up socially through the competition not through cooperation with others. Achieving something is believed as a per-sonal interest, not aspiration for common good.

5. Style of living. Suburbs. A lawyer makes a generous income which allows his family to own a big, nice house with lots of land and a swimming pool. Very seldom a condo downtown a big city. A lawyer is surely drives a black car, most often BMW or Mercedes have been mentioned. A lawyer may be ad-dicted to several substances like coffee, alcohol or drugs. $\mathrm{He}$ sleeps rarely, eats light and he is in a good shape. He spends most of his spare time with his friends. The Russian students reported that they believe that lawyers are well-liked and trusted by many people.

6. Family status. A wife and two kids. An average lawyer doesn't spend much time with the family. As he works very hard, he has to be away from home a lot of the time. A few students mentioned that lawyers have no time for real relationships, so they have lots of promiscuous sex.

7. Hobbies. None. His job is the only hobby of his. Spare time, if any, is spent with the kids.

8. Communicative behavior. Obviously lawyers are great at debate and verbally arguing. However, the students are sure that lawyers sometimes lie so that they can satisfy their clients and their cases. They must be able 
to perform well under high amount of pressure. Lawyers are seen as good orators, they cannot be mumbling or nervous when talking to a jury or a witness. They have to be able to handle stress well.

\section{DISCUSSION}

The perceptions of the Russian students highlight the ways in which Ameri-can lawyers have become idealized to a certain extent in the minds of Russian young adults. In the last decade the United States of America became a symbol of wealth and success for Russians as well as for many citizens of other countries, which contributes to this perception and the creation of a lingualcultural type.

There are several interesting things to note in the student perceptions and the recognition of a lingual-cultural type for US attorneys. First, there are socio-linguistic features embedded in this type in terms of education and style of speech. The Russian students may be unaware of the role of power structures, speech pat-terns, and access to good schools in the United States, but their vision of lawyers reveals many aspects of these things. In spite of the fact that Americans are very tolerant to different accents, standard English language is still a means of a social advancement. Pronunciation, lexical choice, grammar, some paralinguistic pecu-liarities, and non-verbal behavior play the role of social markers (Leontovich). The way a lawyer speaks shows that he or she has to be very intelligent and convincing. In order to present their cases, they must be well-organized and very analytical a-bout situation in general; they must be able to hold power over people. If lawyers did not have any power they would not be able to change the judge's mind and get the verdict they hope for. However, proficiency in this kind of language is very dependent upon the type of schooling students have access to. Prestigious schools pay a lot of attention to good speech. In contrast, schools for poorer families where there is language norm deviation (slang, for instance) is more usual. As a result, kids from upper and middle classes are more ready for getting higher positions at work because they possess good language skills and know how to behave.

Additionally, as YUPPIES (Young Urban Professionals) lawyers use mostly the extralinguistic categories this social status. The signals of social identity are u-sually clothes, food, a car, the quality of dwelling, the press a 
person reads. Much like the language, these things are evidence of a perceived "good" upbringing and education. Often in America, that "good" comes with money and access to power. This is why the Russian students perceive US lawyers as largely male and white. This is a widely distributed image, in films, in books, because the US media ma-chine also holds this understanding of who has power in America.

On a sociocultural level, it is interesting to note that the principle with which Americans are brought up, so called "success ethic" - work hard, get ahead, be successful - is strange for Russians. As such, there is a system of social markers associated with "success" in America that the Russian students seem to be very a-ware of, even though the cultural value that informs those markers is distant for them. We all know that the territory factor is spread on the social status as well. For instance, the marker used to describe a social territory in big American companies is the size of the office: the president uses a big office on the top floor, and an a-verage clerk would share an office with other clerks on the lower floors (Leontovich). A dwelling also limits the space the family owns and the size of the dwelling permits judgment about the status of those who live there. The way the house/office looks gives us a picture that a well-educated person lives/works here. A diploma from a well-known university nicely framed hangs on the wall. Also one may find many encyclopedias, dictionaries, and political books stacked all the way up a book shelf nearing the ceiling.

\section{CONCLUSIONS AND SUGGESTIONS}

All in all, the Russian student perceptions of American lawyers are not very far removed from the descriptions of lawyers I find in popular fiction and crime writing. This is not surprising, but it is very interesting to examine the reasons why this perception is so pervasive. I believe that sociolinguistic and sociocultural ele-ments have combined to create a very strong lingual-cultural type in the case of lawyers. This type also reveals very interesting linguistic and cultural patterns that can be used to understand its influence. Overwhelmingly, the students who parti-cipated in the survey said that lawyers are role models. On one level, this makes sense because they associate positive characteristics of American lawyers. I would guess that the fact that a lawyer is very smart, intelligent, well-read, goal-oriented, and a servant of justice serves 
to inform that position. Nevertheless, there is also a common perception that lawyers are arrogant, corrupt, rushed, uncaring, only out to win, and have no respect for anyone they feel is inferior to them. This is when role model should not apply, but it seems that it does. This is one of the most in-teresting aspects of this lingual-cultural type.

Lingual-cultural types, then, can and should inform our language teaching. In this particular instance, the lingual-cultural type of a lawyer has a direct impact on my teaching in a law school. Lingual-cultural types, however, are not confined to this one profession or one type of person, so examining them provides a per-spective from which we can all inform our teaching linguistically and culturally. The results of the study can be used in the courses of Intercultural Communication, Lexicology of the English Language, US studies, Ethno linguistics or Socio-linguistics, which are an inevitable part of any language teacher training education course.

\section{REFERENCES}

Brown, S. 1995. The Witness. New York: Time Warner.

Dmitrieva, O.A. 2004. "Communicative type "Cossack." Intensive teaching of foreign languages: problems of methodology and linguistics. Volgograd.

-----. 2007. "Lingual-cultural Types of Russia and France of the $19^{\text {th }}$ Century" (dissertation brochure). Volgograd.

Kushner, T. 1995. Angels in America. Perestroika. New York: Theatre Communications Group.

Karasik, V.I. 2004. "Communicative Type: aspects of studying." Axiological Linguistics: aspects of studying. Volgograd.

------. 2002. The Language of Social Status. Moscow: Gnozis.

Leontovich, O.A. 2002. Russians and Americans: Paradoxes of Intercultural Communication. Volgograd: Peremena.

United States. Constitution, Amendment 6. 1791.

Yarmakhova, E.A. 2004. "Communicative type 'comic' in the English linguaculture." Intensive teaching of foreign languages: problems of methodology and linguistics. Volgograd. 